\title{
Distribution of epiphytic macrolichens in relation to remnant trees in a multiple-age Douglas-fir forest
}

\author{
Stephen C. Sillett and Matthew N. Goslin
}

\begin{abstract}
Alternatives to clear-cutting are being implemented to increase biodiversity of managed forests in the Pacific Northwest. Lichens are an integral component of old growth, but lichen biomass develops slowly in forests. We evaluated the long-term potential of live tree retention for lichen conservation in Douglas-fir (Pseudotsuga menziesii (Mirb.) Franco) forests. We sampled lichen litterfall in a 2-ha stand that contained 200- to 600-year-old remnant trees scattered in a forest composed mostly of 100-year-old trees that established following fire. We used association, principal components, and regression analyses to relate lichen litterfall biomass to the proximity of remnant trees. Two epiphytic lichens were strongly associated with remnant trees: the foliose cyanolichen Lobaria oregana (Tuck.) Müll. Arg. and the fruticose green algal lichen Sphaerophorus globosus (Hudson) Vainio. Biomass of both species was highest near remnant trees, and biomass was slightly higher within groves of remnant trees than it was at the edges of these groves or near isolated trees. Lichens appear to have persisted on remnant trees through the last fire and are slowly recolonizing younger trees from this source of propagules. Retention of live trees, maintenance of hardwoods, and longer rotation periods have great potential to maintain old-growth-associated lichens in at least some managed forests.
\end{abstract}

Résumé : Dans la région du nord-ouest du Pacifique, on applique d'autres traitements que la coupe à blanc aux forêts aménagées afin d'augmenter leur biodiversité. Les lichens constituent une partie intégrante des vieux peuplements, mais la biomasse lichénique se développe lentement dans les forêts. Les auteurs ont évalué le potentiel à long terme du maintien des arbres vivants pour la conservation des lichens dans les forêts de sapin de Douglas (Pseudotsuga menziesii (Mirb.) Franco). Ils ont échantillonné la litière lichénique tombée au sol dans un peuplement de 2 ha qui comprenait des vétérans âgés de 200 à 600 ans, dispersés dans une forêt composée principalement d'arbres âgés de 100 ans, établie après feu. Des analyses d'association, en composante principale et de régression ont été utilisées pour relier la biomasse de la litière tombée au sol à la proximité des vétérans. Deux lichens épiphytes étaient fortement associés aux vétérans : un lichen foliacé à cyanobactéries, le Lobaria oregana (Tuck.) Müll. Arg., et un lichen fruticuleux à algues vertes, le Sphaerophorus globosus (Hudson) Vainio. La biomasse de chacune de ces deux espèces était la plus élevée près des vétérans, et légèrement plus élevée dans les groupes de vétérans qu'en bordure de ceux-ci ou près des arbres isolés. Les lichens semblent avoir persisté sur les vétérans pendant le dernier incendie et avoir lentement recolonisé, à partir de cette source de propagules, les arbres plus jeunes. Le maintien des arbres vivants, la conservation des feuillus et une révolution plus longue représentent un grand potentiel pour la conservation des lichens associés aux vieux peuplements, du moins dans quelques forêts aménagées.

[Traduit par la Rédaction]

\section{Introduction}

Epiphytic lichens are an integral but vulnerable component of many temperate forest ecosystems, where they contribute to nutrient cycles (Pike 1978; Knops et al. 1991), provide food and habitat for animals (Stiles 1978; Carroll 1979; Maser et al. 1985; Hayward and Rosentreter 1994), and constitute a major part of species diversity (Lesica et al. 1991). In general, old forests support higher epiphytic lichen biomass than young forests, and many epiphytic species are closely associated with old growth (McCune 1993; Selva

Received August 6, 1998. Accepted January 28, 1999.

S.C. Sillett. ${ }^{1}$ Department of Biological Sciences, Humboldt State University, Arcata, CA 95521, U.S.A.

M.N. Goslin. Department of Forest Science, Oregon State University, Corvallis, OR 97331, U.S.A.

${ }^{1}$ Corresponding author. e-mail: scs6@axe.humboldt.edu
1994; USDA 1994; Esseen et al. 1996). Human activities can have severe and lasting effects on epiphytic lichens in temperate forests. For example, air pollution and forest management have greatly reduced the abundance and distribution of many lichen species in Europe (Rose 1988, 1992).

The ongoing reassessment of forest management practices in the Pacific Northwest has included discussions of lichen conservation (FEMAT 1993; Rosentreter 1995). Alternatives to clear-cutting, such as the retention of large, live trees in cutting units for the duration of stand rotation, are being implemented to increase structural complexity of managed forest canopies (Franklin 1992; Swanson and Franklin 1992). In contrast to young forests, old-growth Douglas-fir forests in this region support a high biomass and diversity of epiphytic lichens, including many nitrogen-fixing species (Pike et al. 1975; Sillett 1995). Nitrogen fixed by these cyanolichens represents a major input to this nitrogenlimited ecosystem (Pike 1978; Denison 1979; Sollins et al. 1980). Live tree retention may enable old-growth-associated 
Fig. 1. Stem map of the Eagle Rock RS in western Oregon. Locations of remnant trees and hardwoods are indicated for the 2-ha stand and a $25 \mathrm{~m}$ wide buffer around the perimeter of the stand. Crown projected areas and crown centers are shown for remnant Douglasfir trees. Elevation contours are drawn at 5-m intervals, beginning with the 700-m contour in the southeastern corner and extending to the $800-\mathrm{m}$ contour in the northwestern corner of the stand. The position of a year-round stream just beyond the eastern boundary is also indicated.

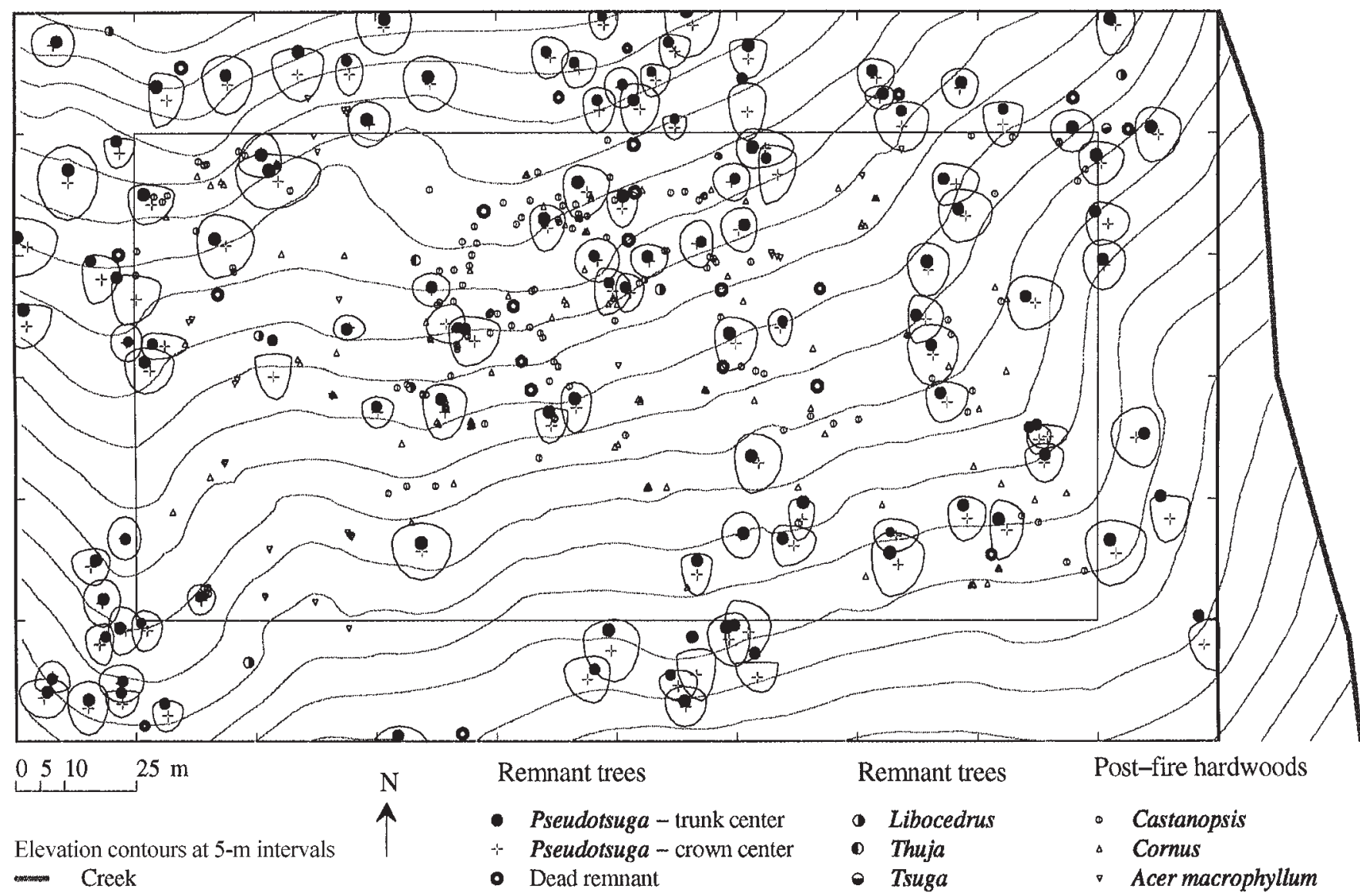

lichens to persist in managed forests, thereby enhancing productivity and biodiversity of these ecosystems. Lichen populations on retained trees could serve as a source of propagules for inoculation of the regenerating forest if the young canopy provides suitable lichen habitat and if lichens can persist on retained trees.

We evaluated the long-term potential of live tree retention for lichen conservation in Douglas-fir forests. Lichen litterfall biomass was compared with the distribution of remnant trees (i.e., >200-year-old survivors of multiple fires) in a natural, multiple-age forest containing predominantly 100year-old trees. We had two major objectives: $(i)$ to determine if remnant trees influence the composition of lichen litterfall in this stand and (ii) to assess the spatial scale(s) of remnant tree effects on the biomass of old-growth-associated lichen species.

\section{Methods}

\section{Study site}

The site of this investigation is a 2-ha reference stand near Eagle Rock in the Detroit Ranger District of the Willamette National Forest, western Oregon $\left(40^{\circ} 47^{\prime} \mathrm{N}, 122^{\circ} 3^{\prime} \mathrm{W}\right)$. This stand (hereafter Eagle Rock RS) represents the Tsuga heterophylla / Berberis nervosa plant association (Hemstrom et al. 1987) of the Tsuga heterophylla Zone (Franklin and Dyrness 1973). Average annual rainfall is $1.9 \mathrm{~m}$ with over $90 \%$ of the precipitation occurring from October through June (Daly et al. 1994). The average annual temperature is $9^{\circ} \mathrm{C}$, with January and July means of 0.5 and $16.5^{\circ} \mathrm{C}$, respectively (National Weather Service). Elevation ranges from 700 to $800 \mathrm{~m}$.

Topography is relatively uniform (average slope 40-60\%) and south facing in all but two regions of the Eagle Rock RS (Fig. 1). The eastern edge of the stand grades into a southeast-facing riparian slope. A small ridge adjoining a seep traverses the western edge of the stand. Vegetation on the lower portion of the ridge is particularly distinctive. It grades into the drier Pseudotsuga menziesii - Tsuga heterophylla / Berberis nervosa plant association (Hemstrom et al. 1987). The canopy is sparse here, and cyanolichens cover lower trunks and branches of conifers in the wellilluminated understory. Throughout the rest of the stand, however, cyanolichens are relatively scarce in the understory, attaining much greater abundance higher up in the conifers and on hardwoods (see Discussion).

Canopy vegetation in the Eagle Rock RS is heterogeneous because of a complex fire history (Goslin 1997). A series of three moderate-intensity fires occurred in 1848, 1870, and 1892. Fire intensity was higher in some portions of the stand than others, killing large trees in several areas. Some incense cedar (Libocedrus decurrens Torr., 1.5/ha) and western redcedar (Thuja plicata Donn., 0.5/ha) survived the fires, but 93\% (26/ha) of the remnant trees are Douglas-fir (Pseudotsuga menziesii (Mirb.) Franco; 
Fig. 2. Geometry of 16-sided polygons representing projected crown areas of remnant trees. Trunk center at crown base is adjusted for tree lean. See text for equations and definitions of symbols.

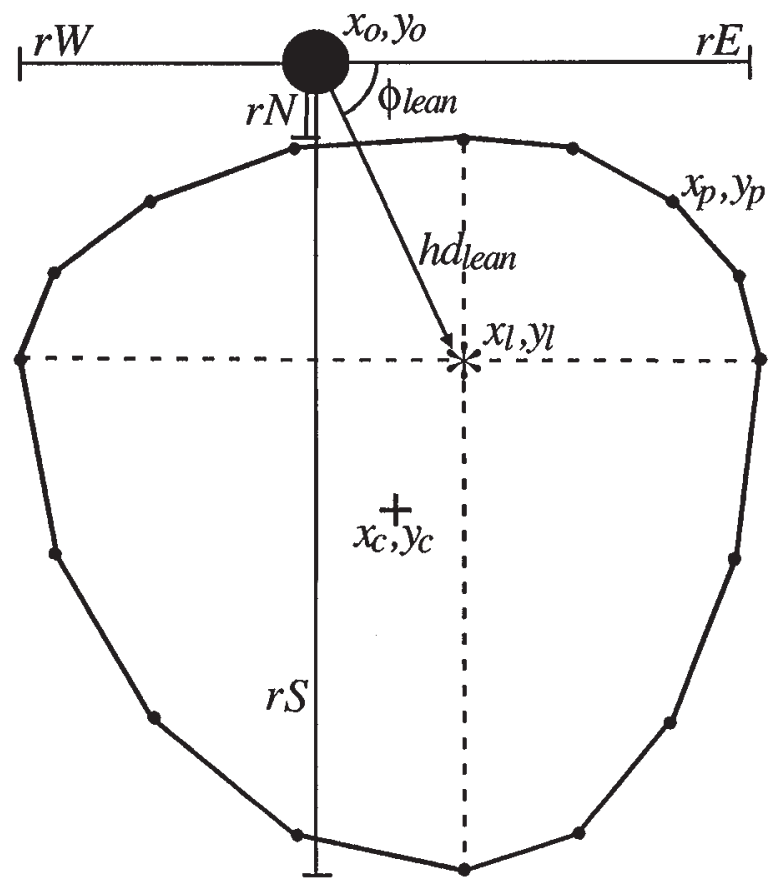

Fig. 1). These large trees are up to $63 \mathrm{~m}$ tall, $1.7 \mathrm{~m}$ diameter at breast height $(\mathrm{DBH})$, and 600 years old. Most of the remnant tree crowns are asymmetrical with greater crown radii on the south (mean $6.5 \mathrm{~m}$ ) versus the north (mean $2.6 \mathrm{~m}$ ) side of the trees (Fig. 1). The regenerating forest is composed primarily of Douglas-fir (721.5/ha) as well as smaller amounts of western hemlock (Tsuga heterophylla (Raf.) Sarg.; 192.5/ha), western redcedar (50.5/ha), Pacific yew (Taxus brevifolia Nutt.; 6.5/ha), and incense cedar (5.5/ha). Three hardwood tree species are also present (in decreasing order of abundance): giant chinkapin (Castanopsis chrysophylla (Dougl.) A. DC.; 66.5/ha), Pacific dogwood (Cornus nuttallii Aud.; 55.5/ha), and bigleaf maple (Acer macrophyllum Pursh; 13/ha). Vine maple (Acer circinatum Pursh) is prevalent in the understory throughout the stand. Trees in the regenerating forest are all less than 150 years old; most are less than 100 years old, having established after the 1892 fire. A complete description of vegetation structure and history in the Eagle Rock RS is presented by Goslin (1997).

\section{Litterfall sampling}

We collected epiphyte litterfall from 231 circular plots (radius $2 \mathrm{~m}$ ) distributed on a $10 \mathrm{~m}$ square grid overlaid onto the 2-ha stand. These plots encompassed over $2900 \mathrm{~m}^{2}$, one eighth of the total surface area of the stand plus about $400 \mathrm{~m}^{2}$ located just outside the reference stand boundaries. All fragments of macrolichens occurring as litterfall were collected from each plot unless they were attached to a fallen branch or tree greater than $10 \mathrm{~cm}$ diameter, or unless they were less than $1 \mathrm{~cm}$ in size (see McCune 1994). We did not use litterfall traps. In the laboratory, litterfall samples were sorted by species, dried at $70^{\circ} \mathrm{C}$ for $24 \mathrm{~h}$, and weighed to the nearest $0.01 \mathrm{~g}$. Nomenclature of lichens follows Esslinger and Egan (1995). Litterfall sampling occurred in August 1993 because a previous study found a close relationship between late summer litterfall biomass and standing crop of lichens in Douglas-fir for- ests (i.e., late summer litterfall represents about $1 \%$ of total biomass in the forest canopy; McCune 1994).

\section{Stem mapping}

We recorded locations of all trees $(\mathrm{DBH}>5 \mathrm{~cm})$ in the Eagle Rock RS using triangulation survey techniques (Pabst et al. 1993; Goslin 1997). We also mapped remnant trees in a $25 \mathrm{~m}$ wide buffer around the perimeter of the 2-ha stand (Fig. 1). Cartesian coordinates of trees were calculated using a SAS code written by R. Pabst. We measured diameter at breast height of all trees $(\mathrm{DBH}>5 \mathrm{~cm})$ with a DBH tape. We measured total height and height to crown base for remnant trees using the pole-tangent method (Curtis and Bruce 1968). We also measured crown radii of remnant trees in each cardinal direction by estimating the crown edge with vertical sightings using a clinometer. Finally, we measured the lean direction and vertical angle of leaning trunks (i.e., from trunk base to crown base) of all remnant trees with a compass and a clinometer.

We constructed 16-sided polygons to represent tree crown projected areas (Fig. 2). Crown asymmetry was maintained in these projections by using the measured crown radii for each cardinal direction rather than an average crown radius. Since many remnant trees had substantial lean, crown projections were centered on the coordinates of the trunk at crown base $\left(x_{1}, y_{1}\right)$ rather than the original trunk coordinates at tree base $\left(x_{0}, y_{0}\right)$. We calculated the coordinates of the trunk at crown base as

$$
x_{1}=x_{\mathrm{o}}+\mathrm{HD}_{\text {lean }} \times \cos \phi_{\text {lean }}
$$

and

$$
y_{1}=y_{\mathrm{o}}+\mathrm{HD}_{\text {lean }} \times \sin \phi_{\text {lean }}
$$

where $\phi_{\text {lean }}$ is the lean direction. We calculated the horizontal distance of the trunk's displacement at crown base, $\mathrm{HD}_{\text {lean }}$, as

$$
\text { [3] } \quad \mathrm{HD}_{\text {lean }}=H_{\mathrm{cb}} \times \mathrm{VA}_{\text {lean }}
$$

where $H_{\mathrm{cb}}$ is the height to crown base and $\mathrm{VA}_{\text {lean }}$ is the vertical angle of the lean. For each quadrant around the tree, coordinates of intermediate points between the measured crown radii were calculated along independent quarter ellipses as

$$
x_{p}=x_{1}+\left|r X-\left(x_{1}-x_{\mathrm{o}}\right)\right| \sin \theta
$$

and

$$
y_{p}=y_{1}+\left|r Y-\left(y_{1}-y_{\mathrm{o}}\right)\right| \cos \theta
$$

where $r X$ is the $\mathrm{E}$ or $\mathrm{W}$ radius defining the quadrant, $r Y$ is the $\mathrm{N}$ or $S$ radius defining the quadrant, and $x_{p}$ and $y_{p}$ are the coordinates of points along each quarter ellipse calculated at $\theta=\pi / 8$ intervals. We calculated the center of each remnant tree's crown $\left(x_{\mathrm{c}}, y_{\mathrm{c}}\right)$ as the center of the full ellipse defined by the two crown diameters. We estimated the volume of remnant tree crowns using crown length and average crown radius in equations derived for old-growth Douglas-fir, which assume a parabolic crown shape (Van Pelt and North 1996). We incorporated all tree coordinate and attribute data into a geographic information system (GIS) database, creating GIS point coverages joining tree attributes and locations. GIS facilitated analysis of additional coverages, such as the polygon coverages representing tree crowns, in conjunction with mapped stem data and litterfall plot centers.

\section{Generation of proximity variables}

We used ARC/INFO (ESRI 1995) and SAS Institute Inc. (1988) to generate 16 variables describing the proximity of litterfall plots to remnant trees and the size of proximate remnant trees. These proximity variables refer to a common coordinate plane and fall into three categories: $(i)$ single-tree distance variables, (ii) singletree size variables, and (iii) multiple-tree variables. Single-tree 
distance variables include three measures of distance between litterfall plot centers and the nearest remnant Douglas-fir tree trunk center (DTRUNK), crown center (DCENTER), and crown edge (DEDGE). Single tree size variables include diameter at breast height (DBH), total height (HEIGHT), crown area (AREA), and crown volume (VOLUME) of the remnant tree with the nearest crown center. Multiple tree variables incorporate information from multiple trees without accounting for distances to individual trees. These variables address issues of spatial scale, however, by using incremental search radii to determine inclusion of remnant trees. We calculated basal area variables by summing basal areas of all remnant trees within fixed radius plots of 5-25 m centered on litterfall plots (BA5, BA10, BA15, BA20, BA25). We included remnant trees on the basis of whether their crown center, rather than their trunk center, fell within the search radius. Basal area measures were calculated using a program written by B. Marks. We summed surface areas of those portions of projected crown polygons that fell within intercepting search radii of 5 and $10 \mathrm{~m}$ centered on litterfall plots (O5AREA, O10AREA). Using the same approach, we estimated the amount of crown volume falling within search radii of 5 and $10 \mathrm{~m}$ (O5VOLUME, O10VOLUME). These last two variables assume that crown volume of each remnant tree is evenly distributed over its projected crown polygon.

\section{Statistical analyses}

We used the procedure CROSSTABS in SPSS/PC+ (SPSS, Inc. 1988) to perform association analyses. These analyses tested whether individual lichen species occurred close to a particular kind of tree more or less often than expected by chance. For each kind of tree (i.e., remnant Douglas-fir, young conifers, and hardwoods by species), we divided litterfall plots into two categories: those with plot centers within $5 \mathrm{~m}$ of a tree and those with plot centers over $5 \mathrm{~m}$ away from the nearest tree. DCENTER was used for remnant trees and distance to nearest trunk was used for hardwood trees. A $2 \times 2$ contingency table was generated for each tree - lichen species pair. The likelihood ratio $G$ (Sokal and Rohlf 1995) was used as the test statistic.

We explored potential effects of remnant trees on epiphytic lichen distribution in the Eagle Rock RS by relating proximity variables to lichen litterfall biomass via regression analysis. Average biomass values $\left(\mathrm{g} / \mathrm{m}^{2}\right)$ of individual lichen species in each litterfall plot were used as the dependent variables. When necessary, dependent variables were square-root transformed prior to analysis to alleviate positive skews and normalize residuals. Because there was strong multicollinearity among the proximity variables, we used principal component analysis (PCA) to derive orthogonal linear combinations, or components, of these variables (McCune and Mefford 1995). The amount of variation extracted by a component was calculated as its eigenvalue divided by 16 , the number of proximity variables used in the PCA. Significant components (eigenvalues >1) were then used as independent variables in regression analysis. Interpretation of these independent variables was based on correlations $(r)$ between the original proximity variables and the principal components themselves. We applied multipleregression analysis to independent variables and a categorical variable representing the 14 litterfall plots located on the anomalous lower ridge (see Study site section above). Use of this categorical variable in multiple regression allowed us to assess the amount of variation in lichen litterfall biomass attributable to the distinctive environment of the lower ridge without reducing either sample size or total variation explained by the analysis.

Contour plots of lichen biomass and independent variables across the Eagle Rock RS were generated with SigmaPlot for Windows (Jandal Corp. 1994). In these plots, a $5 \mathrm{~m}$ square grid was interpolated from the original $10 \mathrm{~m}$ square grid by an inverse distance weighting method such that one quarter of the grid points coincided with litterfall plot centers. We used interpolation to smooth contour lines by placing less emphasis on distant points.

\section{Results}

Fifty macrolichen species were encountered in the 231 litterfall plots (Table 1). Two species dominated epiphyte assemblages, contributing over $4 \mathrm{~kg} / \mathrm{ha}$ to litterfall: the pendant green algal lichen Alectoria sarmentosa and the foliose cyanolichen Lobaria oregana. Six other species also occurred in most of the plots (Hypogymnia enteromorpha, Hypogymnia imshaugii, Hypogymnia inactiva, Platismatia glauca, Platismatia herrei, and Sphaerophorus globosus), but these species each contributed less than $1 \mathrm{~kg} / \mathrm{ha}$ to litterfall. Only one species, Platismatia glauca, was found in every plot. Fourteen species were found in only one or two plots. About one third of total lichen litterfall biomass was contributed by cyanolichens. Finally, bryophytes were sparse in the forest canopy; there were no thick moss mats in the crowns of several remnant trees that we surveyed.

Association analyses revealed several significant associations between lichen species and particular kinds of trees (Table 1). Six species (Bryoria friabilis, Letharia vulpina, Lobaria oregana, Lobaria scrobiculata, Sphaerophorus globosus, and Sticta beauvoisii) were positively associated with remnant Douglas-fir trees, occurring more frequently in litterfall plots near $(<5 \mathrm{~m})$ remnant trees than in plots farther away from remnant trees. Eight cyanolichen species (Lobaria oregana, Lobaria pulmonaria, Lobaria scrobiculata, Peltigera collina, Peltigera neopolydactyla, Pseudocyphellaria anthraspis, Pseudocyphellaria crocata, and Sticta beauvoisii) were positively associated with hardwood species. No lichens were associated with young conifers. Neither total lichen biomass nor lichen species richness were associated with particular kinds of trees. Only two spatial associations were highly significant $(p<0.001)$ : those among remnant Douglas-fir trees and both Lobaria oregana and Sphaerophorus globosus (Table 1). Additional analyses focused on these two associations.

Many of the variables describing the proximity of remnant trees to litterfall plots were significantly correlated with biomass of Lobaria oregana and Sphaerophorus globosus (Table 2). Biomass of both species decreased with increasing distance from the nearest remnant tree. A scatterplot of Lobaria oregana biomass versus DEDGE clearly illustrates this trend (Fig. 3). There were no significant correlations between biomass of either species and size of the nearest remnant tree. Multiple-tree variables were significantly correlated biomass of both species, but correlations were highest for variables within 5 or $10 \mathrm{~m}$ of litterfall plot centers. The significant correlation of Lobaria oregana biomass with the categorical variable "lower ridge" indicates that biomass of this lichen was generally higher here than elsewhere in the reference stand. The first and third principal components were also significantly correlated with biomass of both species (see below).

Severe multicollinearity among the proximity variables was eliminated by PCA, which extracted three significant components accounting for $80 \%$ of the total variation in these 16 variables (Table 3). Eleven proximity variables were strongly correlated $(r>0.5)$ with the first component 
Table 1. Summary of macrolichen litterfall composition in the Eagle Rock RS, western Oregon.

\begin{tabular}{|c|c|c|c|c|}
\hline & \multicolumn{2}{|c|}{ Biomass (g/ha) } & \multirow{2}{*}{$\begin{array}{l}\% \\
\text { Frequency }\end{array}$} & \multirow{2}{*}{$\begin{array}{l}\text { Spatial } \\
\text { associations }\end{array}$} \\
\hline & Mean & SE & & \\
\hline \multicolumn{5}{|l|}{ Cyanolichens } \\
\hline Fuscopannaria saubinetii & 0.45 & 0.37 & 0.9 & \\
\hline Lobaria oregana & 4026.28 & 454.26 & 90.0 & $\mathrm{rPM}^{* *}, \mathrm{CN}^{*}$ \\
\hline Lobaria pulmonaria & 715.99 & 268.91 & 24.7 & $\mathrm{AC}^{*}, \mathrm{CN}^{*}$ \\
\hline Lobaria scrobiculata & 19.47 & 15.97 & 2.2 & $\mathrm{rPM}^{*}$ \\
\hline Nephroma helveticum & 0.14 & 0.16 & 0.4 & \\
\hline Nephroma laevigatum & 0.10 & 0.10 & 0.4 & \\
\hline Nephroma occultum & 0.48 & 0.37 & 0.9 & \\
\hline Peltigera collina & 3.82 & 3.19 & 0.9 & $\mathrm{AM}^{*}$ \\
\hline Peltigera neopolydactyla & 0.86 & 0.84 & 0.4 & $\mathrm{AM}^{*}$ \\
\hline Pseudocyphellaria anomala & 15.23 & 5.97 & 9.5 & \\
\hline Pseudocyphellaria anthraspis & 37.72 & 17.54 & 4.3 & $\mathrm{CC}^{*}, \mathrm{CN}^{*}$ \\
\hline Pseudocyphellaria crocata & 0.10 & 0.10 & 0.4 & $\mathrm{AM}^{*}$ \\
\hline Pseudocyphellaria rainierensis & 6.03 & 5.24 & 1.3 & \\
\hline Sticta beauvoisii & 1.83 & 1.62 & 0.9 & $\mathrm{rPM}^{*}$ \\
\hline \multicolumn{5}{|l|}{ Foliose chlorolichens } \\
\hline Ahtiana pallidula & 0.34 & 0.26 & 0.9 & \\
\hline Esslingeriana idahoensis & 14.54 & 5.13 & 6.5 & \\
\hline Hypogymnia apinnata & 19.26 & 6.13 & 4.8 & \\
\hline Hypogymnia enteromorpha & 887.62 & 40.58 & 99.6 & \\
\hline Hypogymnia imshaugii & 509.61 & 27.91 & 97.0 & \\
\hline Hypogymnia inactiva & 980.15 & 49.06 & 97.8 & \\
\hline Hypogymnia metaphysodes & 4.06 & 1.57 & 3.9 & \\
\hline Hypogymnia occidentalis & 11.71 & 5.03 & 3.0 & \\
\hline Hypogymnia physodes & 14.02 & 3.30 & 9.5 & \\
\hline Hypogymnia rugosa & 0.07 & 0.05 & 0.4 & \\
\hline Hypogymnia tubulosa & 7.48 & 2.25 & 6.5 & \\
\hline Parmelia pseudosulcata & 1.52 & 0.63 & 3.0 & \\
\hline Parmelia saxatilis & 2.34 & 1.26 & 2.6 & \\
\hline Parmelia sulcata & 17.19 & 9.84 & 5.2 & \\
\hline Parmeliopsis hyperopta & 0.03 & 0.05 & 0.4 & \\
\hline Platismatia glauca & 967.16 & 53.88 & 100.0 & \\
\hline Platismatia herrei & 193.74 & 18.48 & 52.8 & \\
\hline Platismatia stenophylla & 80.47 & 9.27 & 43.3 & \\
\hline Tuckermannopsis chlorophylla & 17.29 & 3.35 & 17.3 & \\
\hline Tuckermannopsis orbata & 31.07 & 5.03 & 26.8 & \\
\hline \multicolumn{5}{|l|}{ Pendant fruticose lichens } \\
\hline Alectoria sarmentosa & 4734.76 & 322.63 & 99.6 & \\
\hline Alectoria vancouverensis & 26.28 & 9.63 & 6.1 & \\
\hline Bryoria capillaris & 24.39 & 5.50 & 16.5 & \\
\hline Bryoria friabilis & 76.58 & 11.68 & 43.7 & $\mathrm{rPM} *$ \\
\hline Bryoria fuscescens & 9.34 & 3.82 & 5.6 & \\
\hline Bryoria pseudofuscescens & 6.89 & 2.83 & 4.8 & \\
\hline Bryoria sp. A & 13.57 & 5.13 & 10.4 & \\
\hline Nodobryoria oregana & 57.84 & 12.41 & 33.3 & \\
\hline Usnea spp. & 341.36 & 47.17 & 59.7 & \\
\hline \multicolumn{5}{|l|}{ Other fruticose lichens } \\
\hline Cladonia spp. & 4.65 & 2.20 & 2.6 & \\
\hline Evernia prunastri & 0.31 & 0.26 & 0.9 & \\
\hline Letharia vulpina & 1.48 & 1.05 & 0.9 & $\mathrm{rPM} *$ \\
\hline Ramalina farinacea & 0.24 & 0.26 & 0.4 & \\
\hline Sphaerophorus globosus & 395.27 & 62.04 & 61.5 & $\mathrm{rPM} * *$ \\
\hline
\end{tabular}

Note: Significant positive associations between lichens and tree species (rPM, remnant Pseudotsuga menziesii; AC, Acer circinatum; AM, Acer macrophyllum; CC, Castanopsis chrysophylla; CN, Cornus nuttallii) are shown using the following symbols: *, $p<0.01 ; * *, p<0.001$. 
Table 2. Correlation coefficients $(r)$ between biomass of two lichen species and 16 variables describing the proximity of remnant Douglas-fir trees to litterfall plots in the Eagle Rock RS, western Oregon ( $n=231$ plots).

\begin{tabular}{|c|c|c|}
\hline & $\begin{array}{l}\text { Lobaria } \\
\text { oregana }\end{array}$ & $\begin{array}{l}\text { Sphaerophorus } \\
\text { globosus }\end{array}$ \\
\hline \multicolumn{3}{|c|}{ Single-tree distance measures } \\
\hline DTRUNK & $-0.420 * *$ & $-0.251 * *$ \\
\hline DCENTER & $-0.490 * *$ & $-0.300 * *$ \\
\hline DEDGE & $-0.486 * *$ & $-0.304 * *$ \\
\hline \multicolumn{3}{|c|}{ Single-tree size measures } \\
\hline $\mathrm{DBH}$ & 0.006 & 0.102 \\
\hline HEIGHT & -0.032 & 0.066 \\
\hline AREA & 0.005 & 0.143 \\
\hline VOLUME & 0.021 & 0.126 \\
\hline \multicolumn{3}{|c|}{ Multiple-tree measures } \\
\hline O5AREA & $0.508 * *$ & $0.472 * *$ \\
\hline O10AREA & $0.474 * *$ & $0.304 * *$ \\
\hline O5VOLUME & $0.464 * *$ & $0.486^{* *}$ \\
\hline O10VOLUME & $0.432 * *$ & $0.305^{* *}$ \\
\hline BA5 & $0.394 * *$ & $0.521 * *$ \\
\hline BA10 & $0.414 * *$ & $0.265^{* *}$ \\
\hline BA15 & $0.266 * *$ & 0.126 \\
\hline BA20 & $0.172 *$ & 0.050 \\
\hline BA25 & 0.116 & 0.058 \\
\hline \multicolumn{3}{|c|}{ Principal components } \\
\hline PC1 & $0.482 * *$ & $0.360 * *$ \\
\hline $\mathrm{PC} 2$ & 0.094 & 0.102 \\
\hline PC3 & $0.236 * *$ & $0.342 * *$ \\
\hline "Lower ridge" & $0.345^{* *}$ & 0.036 \\
\hline
\end{tabular}

Note: Principal components were derived from a PCA of 16 proximity variables. "Lower ridge" is a categorical variable representing 14 plots from the anomalous southwest corner of the stand. Significant correlations are indicated by the following symbols: *, $p<0.01$; **, $p<$ 0.001 .

Table 3. First three principal components from analysis of 16 proximity variables $(n=231$ plots).

\begin{tabular}{lll}
\hline Component & Eigenvalue & $\%$ of Variation \\
\hline PC1 & 8.03 & 50.19 \\
PC2 & 3.07 & 19.16 \\
PC3 & 1.71 & 10.67 \\
\hline
\end{tabular}

(PC1), four with the second component (PC2), and two with the third component (PC3; Table 4). PC1 represented the proximity of litterfall plots to the nearest remnant tree or trees. The highest values of PC1 occurred close to remnant trees, while the lowest values occurred far from remnant trees (Fig. 4). PC2 represented the size of the nearest remnant tree. PC3 represented an interior to edge gradient: highest values occurred in the centers of remnant tree groves (i.e., areas with several remnant trees within 20-25 m), and lowest values occurred near the edges of these groves or near isolated trees (Fig. 5). PC3 contained only that portion
Table 4. Correlation coefficients $(r)$ between 16 proximity variables and the first three principal components ( $n=231$ plots).

\begin{tabular}{|c|c|c|c|}
\hline & PC1 & $\mathrm{PC} 2$ & PC3 \\
\hline \multicolumn{4}{|c|}{ Single-tree distance measures } \\
\hline DTRUNK & 0.854 & 0.284 & -0.052 \\
\hline DCENTER & 0.902 & 0.241 & 0.041 \\
\hline DEDGE & 0.914 & 0.090 & 0.042 \\
\hline \multicolumn{4}{|c|}{ Single-tree size measures } \\
\hline DBH & -0.078 & 0.804 & 0.127 \\
\hline HEIGHT & -0.155 & 0.777 & 0.181 \\
\hline AREA & -0.044 & 0.848 & -0.118 \\
\hline VOLUME & -0.124 & 0.940 & -0.024 \\
\hline \multicolumn{4}{|c|}{ Multiple-tree measures } \\
\hline O5AREA & -0.848 & -0.008 & -0.454 \\
\hline O10AREA & -0.941 & 0.016 & -0.054 \\
\hline O5VOLUME & -0.823 & 0.144 & -0.422 \\
\hline O10VOLUME & -0.904 & 0.197 & -0.026 \\
\hline BA5 & -0.649 & -0.009 & -0.494 \\
\hline BA10 & -0.858 & -0.035 & 0.002 \\
\hline BA15 & -0.745 & -0.007 & 0.446 \\
\hline BA20 & -0.684 & -0.055 & 0.628 \\
\hline BA25 & -0.571 & -0.036 & 0.642 \\
\hline
\end{tabular}

of the variation in BA20 and BA25 that was uncorrelated with PC1 (Table 4).

Multiple regression analysis showed that PC1 (hereafter the "nearest remnant effect") and PC3 (hereafter the "grove effect") accounted for about one quarter of the variation in litterfall biomass of both Lobaria oregana and Sphaerophorus globosus (Table 5). For Lobaria oregana, the nearest remnant effect was much stronger than the grove effect. Biomass of both species was highest near remnant trees, and biomass was slightly higher within groves of remnant trees than it was at the edges of these groves or near isolated trees. Lichen biomass was not correlated with variation in the size of remnant trees. The distinctive environment of the lower ridge accounted for almost $17 \%$ of the variation in Lobaria oregana biomass, but it was unrelated to the biomass of Sphaerophorus globosus. A contour plot clearly shows the close association of Lobaria oregana with remnant trees (Fig. 6). Biomass of this species was very low $\left(<0.1 \mathrm{~g} / \mathrm{m}^{2}\right)$ in areas lacking remnant trees, except for the lower ridge, where it was high $\left(>1 \mathrm{~g} / \mathrm{m}^{2}\right)$ even where no remnant trees occurred within $20 \mathrm{~m}$. Nevertheless, Lobaria oregana biomass in the lower ridge was still higher near remnant trees (Fig. 3).

\section{Discussion}

\section{Litterfall as a canopy signal}

The close relationship between litterfall biomass and standing crop of epiphytic lichens in Douglas-fir forests allowed us to rapidly survey canopy lichen biomass across 2 ha of heterogeneous forest without directly sampling from tree crowns. The litterfall method was originally intended for use in among-stand comparisons of lichen biomass because it yields accurate estimates of stand-level biomass for 
Fig. 3. Scatterplot of Lobaria oregana litterfall biomass vs. the proximity variable DEDGE. The solid line is the least-squares linear regression line $\left(r^{2}=0.41\right)$ for 215 litterfall plots, excluding 14 plots from the lower ridge and 2 plots from the riparian slope (see Discussion). Plots to the left of the broken line occurred within projected crown areas of remnant Douglas-fir trees. The $Y$-axis is on a square-root scale.

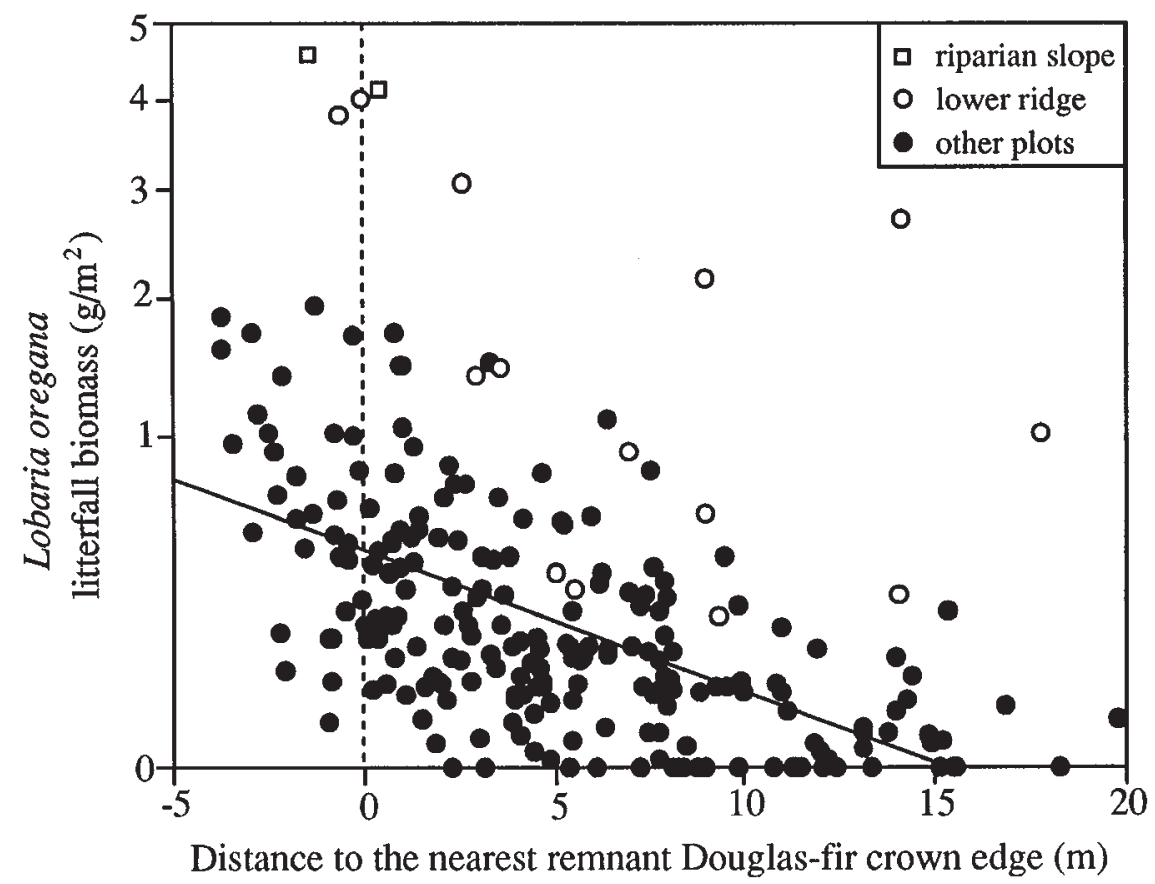

Fig. 4. Contour plot of the 5th, 50th, 65th, 80th, and 95th percentiles of the independent variable PC1 (the nearest remnant effect) in the Eagle Rock RS, western Oregon. Locations of remnant Douglas-fir crown centers are indicated by solid circles.

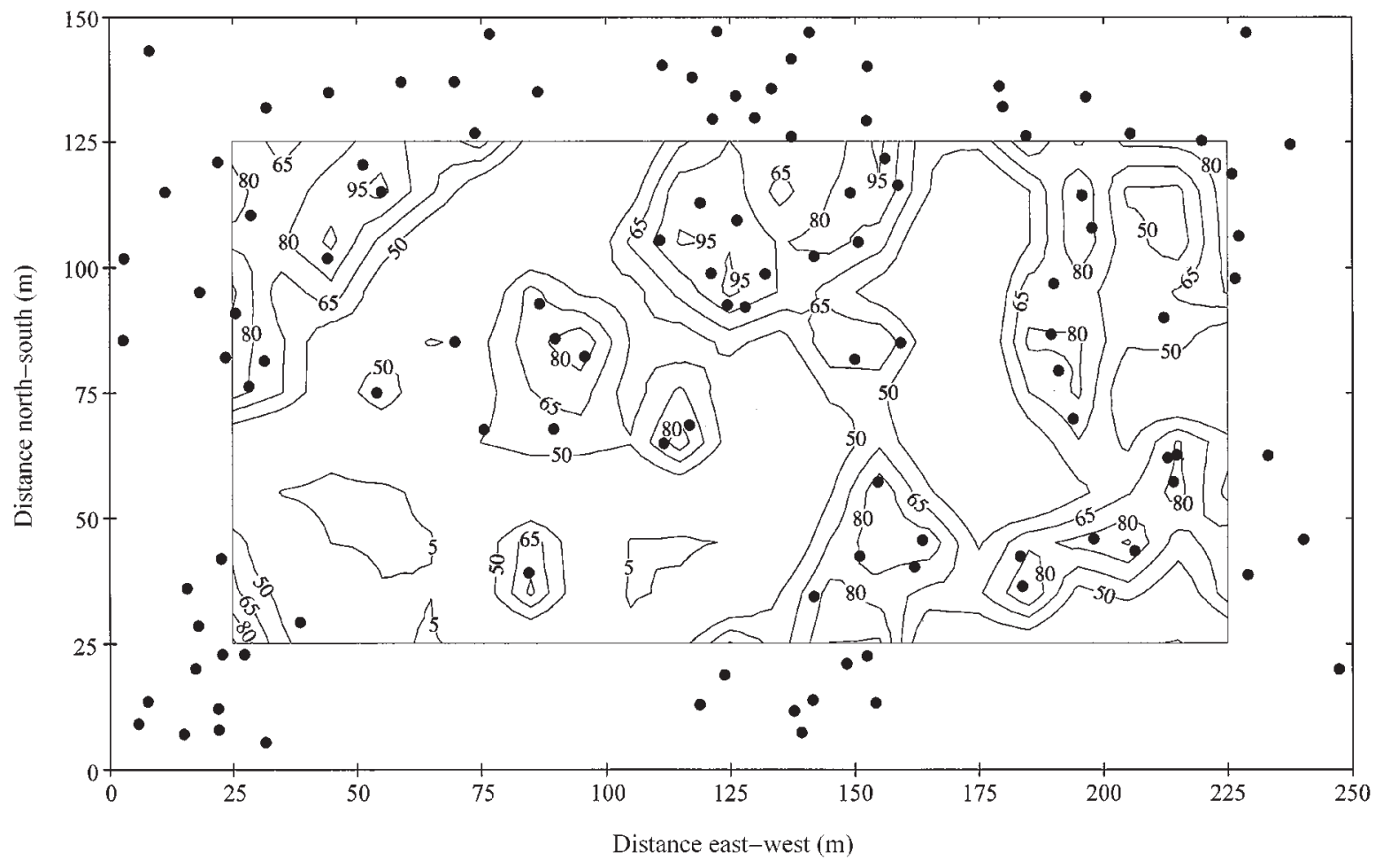

many species (McCune 1994). Our data demonstrate that the method can also be used to assess within-stand distribution patterns of abundant species. Litterfall deposition beneath a tree crown is probably too variable to permit accurate esti- mates of lichen biomass for individual trees, but the bulk of lichen thalli falling from a tree crown are probably deposited within the projected area of that crown. Proximity variables accounting for crown asymmetry (e.g., DCENTER and 
Fig. 5. Contour plot of the 5th, 50th, 65th, 80th, and 95th percentiles of the independent variable PC3 (the grove effect) in the Eagle Rock RS, western Oregon. Locations of remnant Douglas-fir crown centers are indicated by solid circles.

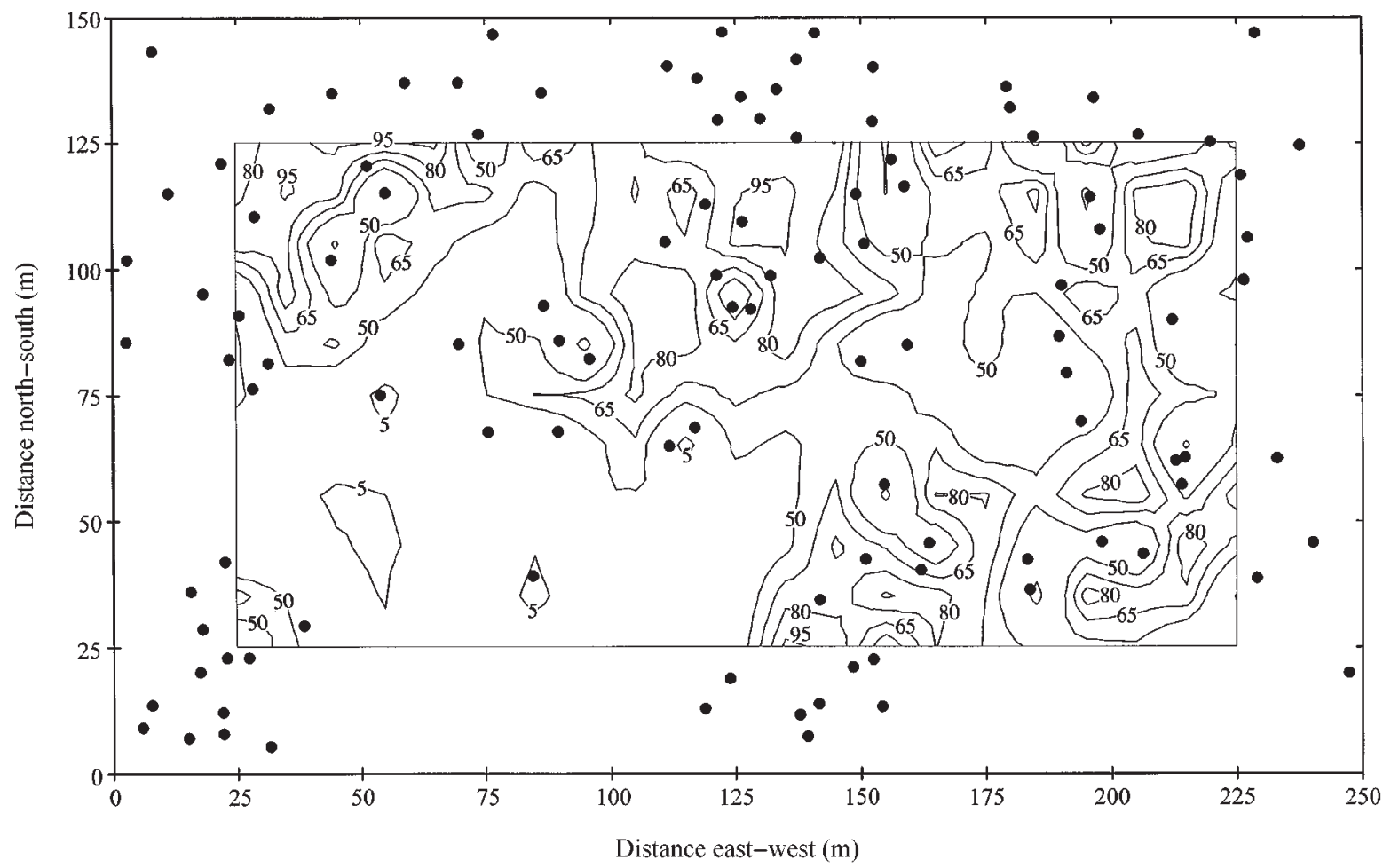

Table 5. Proportion of variation (adjusted $r^{2}$ ) explained by variables in multiple regression analysis of lichen litterfall plots $(n=231)$ in the Eagle Rock RS, western Oregon.

\begin{tabular}{lllllll}
\hline Lichen species & PC1 & PC2 & PC3 & $\begin{array}{l}\text { Lower } \\
\text { ridge }\end{array}$ & $\begin{array}{l}\text { Total } \\
\text { variation }\end{array}$ & $P$ \\
\hline Lobaria oregana & 0.229 & - & 0.030 & 0.168 & 0.434 & $<0.0001$ \\
Sphaerophorus globosus & 0.126 & - & 0.114 & - & 0.240 & $<0.001$ \\
\hline
\end{tabular}

Note: "Lower ridge" is a categorical variable representing 14 plots in the anomalous southwestern corner of the stand. PC1 (the nearest remnant effect), PC2, and PC3 (the grove effect) represent independent variables derived from principal components analysis of the 16 proximity variables.

DEDGE) yielded substantially higher correlations with lichen biomass than those relating only to locations of tree trunks (e.g., DTRUNK).

\section{Remnant tree effects}

Remnant Douglas-fir trees influenced the composition of lichen litterfall more than any other kind of tree in the Eagle Rock RS. Our analyses revealed two independent spatial scales of remnant tree effects on biomass of Lobaria oregana and Sphaerophorus globosus: the nearest remnant effect and the grove effect. The nearest remnant effect is clearly visible in the contour plot of Lobaria oregana litterfall where lichen biomass diminishes rapidly with increasing distance from individual crowns (Fig. 6). The simplest explanation for this effect is that both species are most abundant on remnant trees and that litterfall deposition beneath source trees accounts for much of this pattern. However, limited dispersal of both species from remnant trees into the regenerating canopy has also occurred because we found thalli growing on trunks and branches of young coni- fers and hardwoods. For both species, correlations with multiple-tree variables diminished with increasing search radii, but this decline was more drastic for Sphaerophorus globosus. This suggests that Sphaerophorus globosus litterfall is deposited closer to the source tree than Lobaria oregana litterfall (see Table 2). Sphaerophorus globosus occurred primarily on the trunks and inner branches of remnant trees while Lobaria oregana was more widespread, occurring abundantly on branchlets in the outer crown. The effect of remnant trees on Lobaria oregana biomass clearly extends well beyond the crown edge (see Fig. 3), a pattern attributable, in part, to successful colonization of young trees by Lobaria oregana.

If some lichens are largely restricted to remnant trees, these populations may be relicts from the intact forest canopy that existed prior to the fires. Alternatively, these species may have colonized remnant trees since the fires. Two pieces of evidence point to the former possibility. First, epiphyte assemblages in large trees are resistant to moderate levels of disturbance (Sillett 1995), and some cyanolichens 
Fig. 6. Contour plot of Lobaria oregana litterfall biomass $\left(\mathrm{g} / \mathrm{m}^{2}\right)$ in the Eagle Rock RS, western Oregon. Contour intervals represent a doubling series of litterfall biomass: $0.125,0.25,0.5,1.0,2.0$, and $4.0 \mathrm{~g} / \mathrm{m}^{2}$. Locations of remnant Douglas-fir crown centers are indicated by solid circles.

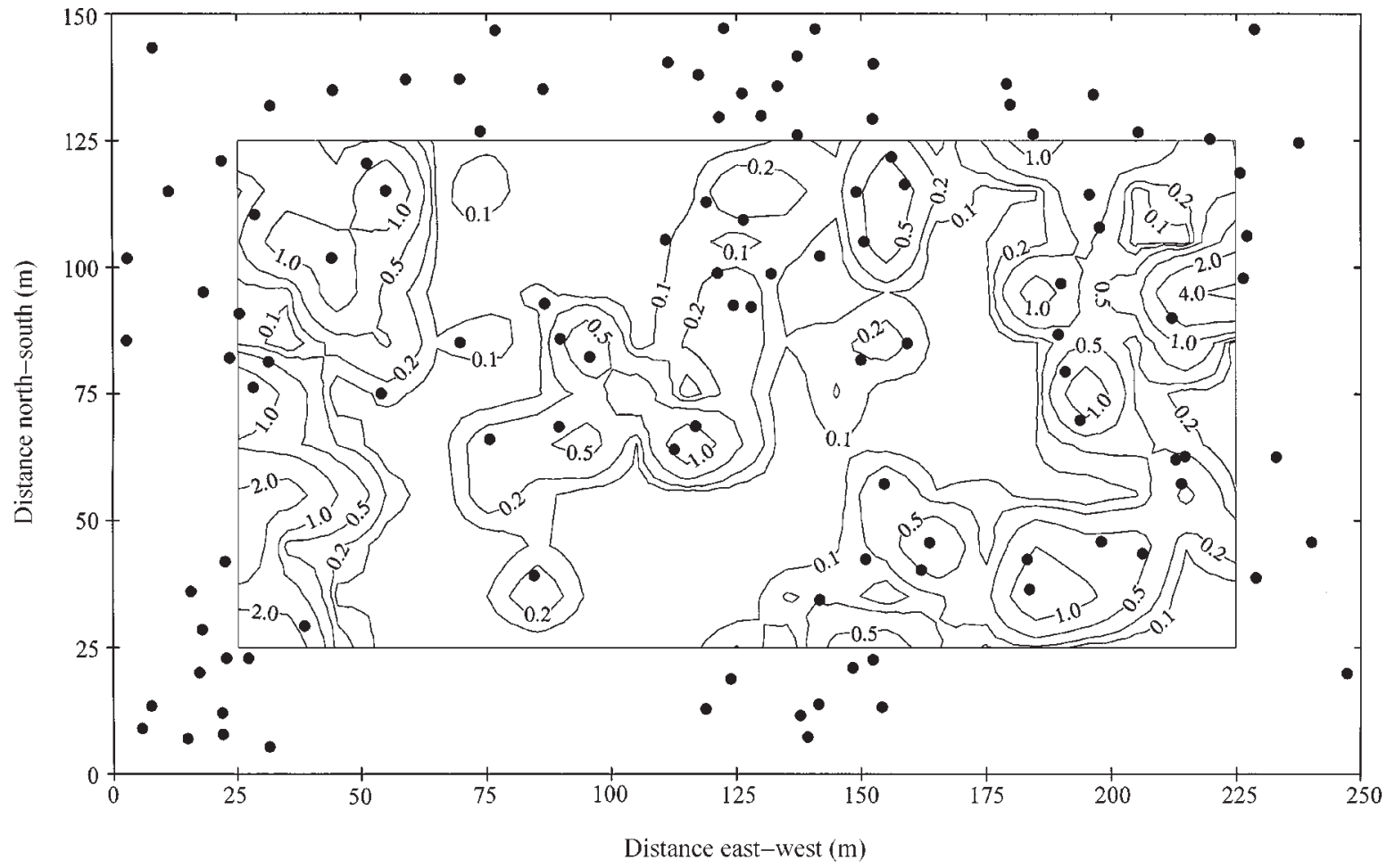

can acclimate to changing environments in tree crowns (Sillett 1994). Second, we found healthy populations of three old-growth-associated cyanolichens (Nephroma occultum, Pseudocyphellaria rainierensis, and Sticta beauvoisii) while climbing remnant trees scattered throughout the stand. These species are scarce or absent in even-aged Douglas-fir forests less than a century old (Neitlich 1993). Potential reasons for their scarcity in younger forests include dispersal limitations (Sillett et al. 1999) and (or) slow growth combined with poor competitive abilities of juvenile thalli (Scheidegger 1995; Gauslaa and Solhaug 1998). Regardless of the cause, these species would not have been able to thoroughly recolonize the Eagle Rock RS had their populations been completely destroyed by the last fire.

The grove effect on biomass of Lobaria oregana and Sphaerophorus globosus is attributable to edge effects. Recall that litterfall biomass of both species was slightly higher within groves of remnant trees than on the edges of groves or near isolated trees. There are few differences in lichen biomass between the forest interior and clearcut edge of humid old-growth Douglas-fir stands, but the drier environment of the Eagle Rock RS might lead to more pronounced edge effects in the canopy, especially in the absence of thick moss mats (Sillett 1995). Exposed trees in the Eagle Rock RS provide fewer suitable habitats for Lobaria oregana and Sphaerophorus globosus than more sheltered trees within groves.

\section{Hardwood effects}

Factors that affect epiphytic lichen habitat (e.g., crown architecture, microclimate, bark chemistry, and bark texture) overlap broadly between tree species. Consequently, few (if any) lichens are truly restricted to a single kind of tree in temperate forests (Schmitt and Slack 1990). Many of the most abundant lichens in the Eagle Rock RS (e.g., Alectoria sarmentosa, $H$. enteromorpha, $H$. imshaugii, $H$. inactiva, Platismatia glauca, Platismatia herrei) were not associated with particular kinds of trees. They occurred on a wide variety of substrates throughout the stand. Associations between several cyanolichens (e.g., Lobaria pulmonaria, Peltigera spp., and Pseudocyphellaria spp.) and hardwoods reflect preferences of these epiphytes for habitat conditions more prevalent on hardwoods than on conifers (Bates 1992; Kuusinen 1994). Furthermore, epiphytic cyanolichens tend to colonize hardwoods more quickly than conifers (Sillett and Neitlich 1996), and cyanolichen diversity in young conifer forests can be high in canopy gaps containing hardwoods (Neitlich and McCune 1997).

\section{Topographic effects}

The highest biomass of Lobaria oregana in the Eagle Rock RS occurred in two areas of the stand possessing distinctive topography: the lower ridge and a trough within the riparian slope (Fig. 6). The lower ridge was the only area of the stand where cyanolichens, including Lobaria oregana, were abundant on the lower trunks and branches of young conifers. Our regression analyses could not determine the cause of Lobaria oregana abundance on the lower ridge, but we suspect a strong role of dispersal effects. A dense grove of remnant trees in the southwestern corner of the stand represents a propagule source that finds its sink on the leeward slope of the ridge; prevailing winds are from the southwest. 
A secondary source of Lobaria oregana propagules are several hardwoods (see Fig. 1), whose crowns may have provided suitable habitat for its initial establishment on the lower ridge. The typically low abundance of Lobaria oregana and other epiphytic cyanolichens in dense, young forests has been attributed to low light availability (Rose 1992), an unfavorable moisture regime (Franklin et al. 1981), or a shortage of suitable substrates (Esseen et al. 1996). Recent experiments, however, demonstrate that particular substrates and microclimates found only in old growth are not essential for establishment of Lobaria oregana in a forest canopy. In the western Oregon Cascades, it is capable of rapid establishment and growth on smooth-barked branches of young conifers as long as there is an adequate source of propagules (Sillett et al. 1999).

The other area of the stand with very high Lobaria oregana litterfall biomass $\left(>2 \mathrm{~g} / \mathrm{m}^{2}\right)$ was located within an east-facing trough along the riparian slope (compare Figs. 1 and 6). The two nearest remnant trees are located on the edge of an area that burned in 1870 but was unaffected by the 1892 fire (Goslin 1997). We found large populations of Lobaria oregana and other cyanolichens (e.g., Sticta beauvoisii) in the crowns of these trees. Canopy humidity is higher here than elsewhere in the stand because of the proximity of a year-round stream located just beyond the eastern boundary of the mapped area (Fig. 1). Abundance of epiphytic cyanolichens is typically higher in riparian areas than in drier sites located farther away from streams (Sillett and Neitlich 1996). Thus, elevated humidity probably contributed to the unusually high Lobaria oregana biomass in this portion of the Eagle Rock RS, which is otherwise south facing and far removed from riparian influence.

\section{Management implications}

The cyanolichen Lobaria oregana is a major nitrogen source in some old-growth Douglas-fir forests (Pike 1978; Denison 1979; Sollins et al. 1980). Maintenance of this species and other cyanolichens in managed forests will increase both biodiversity and ecosystem productivity. Unfortunately, cyanolichen colonization of regenerating forests is a slow process; even a century after the last major fire, Lobaria oregana is still most abundant in the vicinity of remnant trees. The generality of this result from the Eagle Rock RS is supported by a recent study that found a similar pattern in thirteen Douglas-fir forest stands: cyanolichen biomass was 233\% higher in stands with remnant trees than in those without remnant trees (Peck and McCune 1997). Lobaria oregana slowly invades regenerating forest canopies by dispersal from remnant tree crowns. Its persistence on remnant trees after fire indicates that Lobaria oregana populations on remnant trees can serve as a long-term source of propagules in managed forests.

Our results suggest that cyanolichen conservation in at least some managed forests will be facilitated by recently implemented silvicultural practices in the Pacific Northwest. One stand-level component of silviculture being reconsidered is the retention level of live trees in cutting units (Gillis 1990). We expect large, retained trees to mimic remnant trees in terms of their resident epiphytes. Like remnant trees, retained trees will continue to harbor epiphyte populations that can then inoculate younger trees. Retaining groves of live trees rather than scattered, isolated trees may improve the chances for cyanolichen persistence in retained tree crowns because of more favorable canopy microclimates within groves. However, our data indicate that the nearest remnant effect is much stronger than the grove effect for Lobaria oregana. Recent experiments also demonstrated that dispersal, not microclimate, is the major factor limiting development of Lobaria oregana populations in Douglas-fir forests of the western Oregon Cascades (Sillett et al. 1999). Therefore, retaining scattered, isolated trees may lead to more effective dispersal of this species over a broader area.

In addition to live tree retention, a number of other silvicultural practices will contribute to cyanolichen conservation in managed forests. Lengthening rotation ages from 60-100 years to over 100 years will improve chances of successful dispersal and establishment of cyanolichens in regenerating forests. Douglas-fir forests 140-150 years old often have considerable cyanolichen biomass in the canopy (Neitlich 1993; Sillett and McCune 1998). Cyanolichen recruitment is likely to be patchy in the regenerating forest, but some areas will develop a high cyanolichen biomass relatively quickly, much like the lower ridge in the Eagle Rock RS. Maintaining hardwoods will facilitate cyanolichen recovery in managed forests because cyanolichen biomass and diversity can often develop more quickly on hardwoods than on conifers (Neitlich and McCune 1997; Sillett and Neitlich 1996). These populations will serve as secondary sources of propagules for the inoculation of young conifers. Finally, protection of the riparian zone with riparian buffers (Swanson and Franklin 1992) will contribute to cyanolichen conservation because epiphytic cyanolichen biomass is highest near streams or other humid sites (Sillett and Neitlich 1996).

\section{Acknowledgements}

We thank Edward LeBrun, Becca Kolasky, Lewis Goslin, Suzanne Remillard, Dana Blumenthal, Michael LeMaster, Mark Woodward, Coulter Rose, and Andi Eicher for assistance with field work. Fred Rhoades, Trevor Goward, Scott Sillett, Tom Spies, Bruce McCune, George Carroll, Bill Denison, and an anonymous reviewer provided constructive comments on the manuscript. Bruce McCune and Peter Neitlich assisted with the identification of lichens. Bruce McCune and Scott Sillett provided advice on statistical analyses. Financial support was provided by a National Science Foundation Graduate Fellowship and the Pacific Northwest Research Station of the U.S. Forest Service.

\section{References}

Bates, J.W. 1992. Influence of chemical and physical factors on Quercus and Fraxinus epiphytes at Lock Sunart, western Scotland: a multivariate analysis. J. Ecol. 80: 163-179.

Carroll, G.C. 1979. Forest canopies: complex and independent subsystems. Oregon State University Press, Corvallis.

Curtis, R.O., and Bruce, D. 1968. Tree heights without a tape. J. For. 66: 60-61.

Daly, C., Neilson, R.P., and Phillips, D.L. 1994. A statisticaltopographic model for mapping climatological precipitation over mountainous terrain. J. Appl. Meteorol. 33: 140-158.

Denison, W.C. 1979. Lobaria oregana, a nitrogen-fixing lichen in old-growth Douglas-fir forests. In Symbiotic nitrogen fixation in 
the management of temperate forests. Edited by J.C. Gordon, C.T. Wheeler, and D.A. Perry. Forest Research Laboratory, Oregon State University, Corvallis. pp. 266-275.

Environmental Systems Research Institute, Inc. (ESRI) 1995. ARC/INFO, version 7.0 edition. Environmental Systems Research Institute, Inc., Redlands, Calif.

Esseen, P.-A., Renhorn, K.-E., and Pettersson, R.B. 1996. Epiphytic lichen biomass in managed and old-growth boreal forests: effects of branch quality. Ecol. Appl. 6: 228-238.

Esslinger, T.L., and Egan, R.S. 1995. A sixth checklist of the lichen-forming, lichenicolous, and allied fungi of the continental United States and Canada. Bryologist, 98: 467-549.

Forest Ecosystem Management Assessment Team (FEMAT). 1993. Forest ecosystem management: an ecological, economic, and social assessment. U.S. Department of Agriculture and U.S. Department of the Interior, Washington, D.C.

Franklin, J.F. 1992. Scientific basis for new perspectives in forests and streams. In Watershed management: balancing sustainability and environmental change. Edited by R. Naiman. SpringerVerlag, New York. pp. 5-72.

Franklin, J.F., Cromack, K., Denison, W., McKee, A., Maser, C., Sedell, J., and Juday, G. 1981. Ecological characteristics of oldgrowth Douglas-fir forests. U.S. For. Serv. Gen. Tech. Rep. PNW-GTR-118.

Franklin, J.F., and Dyrness, C.T. 1973. Natural vegetation of Oregon and Washington. U.S. For. Serv. Gen. Tech. Rep. PNWGTR-8.

Gauslaa, Y., and Solhaug, K.A. 1998. The significance of thallus size for the water economy of the cyanobacterial old-forest lichen Degelia plumbea. Oecologia, 116: 76-84.

Gillis, A.M. 1990. The new forestry: an ecosystem approach to land management. BioScience, 40: 558-562.

Goslin, M.N. 1997. Development of two coniferous stands impacted by multiple, partial fires in the Oregon Cascades: establishment history and the spatial patterns of colonizing tree species relative to old-growth remnant trees. Master's thesis, Oregon State University, Corvallis.

Hayward, G.D., and Rosentreter, R. 1994. Lichens as nesting material for northern flying squirrels in the northern Rocky Mountains. J. Mammal. 75: 663-673.

Hemstrom, M.A., Logan, S.E., and Pavlat, W. 1987. Plant association and management guides for the Willamette National Forest. U.S. For. Serv. Publ. R6-Ecol-257-1986.

Knops, J.M.H, Nash, T.H., III, Boucher, V.L., and Schlesinger, W.H. 1991. Mineral cycling and epiphytic lichens: implications at the ecosystem level. Lichenologist, 23: 309-321.

Kuusinen, M. 1994. Epiphytic lichen diversity on Salix caprea in old-growth southern and middle boreal forests of Finland. Ann. Bot. Fenn. 31: 77-92.

Lesica, P., McCune, B., Cooper S., and Hong, W.S. 1991. Differences in lichen and bryophyte communities between old-growth and managed second-growth forests in Swan Valley, Montana. Can. J. Bot. 69: 1745-1755.

Maser, Z., Maser, C., and Trappe, J.M. 1985. Food habits of the northern flying squirrel in Oregon. J. Zool. 63: 1084-1088.

McCune, B. 1993. Gradients in epiphyte biomass in three Pseudotsuga-Tsuga forests of different ages in western Oregon and Washington. Bryologist, 96: 405-411.

McCune, B. 1994. Using epiphyte litter to estimate epiphyte biomass. Bryologist, 97: 396-401.

McCune, B., and Mefford, M.J. 1995. PC-ORD. Mulitvariate analysis of ecological data, version 2.0 edition. MjM Software Design, Gleneden Beach, Oreg.
Neitlich, P.N. 1993. Lichen abundance and biodiversity along a chronosequence from young managed stands to ancient forest. Master's thesis, University of Vermont, Burlington.

Neitlich, P.N., and McCune, B. 1997. Hotspots of epiphytic lichen diversity in two young managed forests. Conserv. Biol. 11: 172182.

Pabst, R.J., Goslin, M.N., Splean, S., and Spycher, G. 1993. Using a geographic information system (GIS) to generate stem and log maps from field survey data. Internal Methods Manual. Forest Sciences Laboratory, Oregon State University, Corvallis.

Peck, J., and McCune, B. 1997. Remnant trees and canopy lichen communities in western Oregon: a retrospective approach. Ecol. Appl. 7: 1181-1187.

Pike, L.H. 1978. The importance of epiphytic lichens in mineral cycling. Bryologist, 81: 247-257.

Pike, L.H., Denison, W.C., Tracy, D., Sherwood, M., and Rhoades, F. 1975. Floristic survey of epiphytic lichens and bryophytes growing on old-growth conifers in western Oregon. Bryologist, 78: $389-402$.

Rose, F. 1988. Phytogeographical and ecological aspects of Lobarion communities in Europe. Bot. J. Linn. Soc. 96: 69-79.

Rose, F. 1992. Temperate forest management: its effects on bryophyte and lichen floras and habitats. In Bryophytes and lichens in a changing environment. Edited by J.W. Bates and A.M. Farmer. Oxford University Press, Oxford, U.K. pp. 211233.

Rosentreter, R. 1995. Lichen diversity in managed forests of the Pacific Northwest, U.S.A. In Conservation biology of lichenised fungi. Edited by C. Scheidegger, P.A. Wolseley, and G. Thor. Herausgeber, Birmensdorf, Germany. pp. 103-124.

SAS Institute Inc. 1988. SAS language guide, version 6.03 edition. SAS Institute Inc., Cary, N.C.

Schmitt, C.K., and Slack, N.G. 1990. Host specificity of epiphytic lichens and bryophytes: a comparison of the Adirondack Mountains (New York) and the southern Blue Ridge Mountains (North Carolina). Bryologist, 93: 257-274.

Selva, S.B. 1994. Lichen diversity and stand continuity in the northern hardwoods and spruce-fir forests of northern New England and western New Brunswick. Bryologist, 97: 424-429.

Sillett, S.C. 1994. Growth rates of two epiphytic cyanolichen species at the edge and in the interior of a 700-year-old Douglas-fir forest in the western Cascades of Oregon. Bryologist, 97: 321324.

Sillett, S.C. 1995. Branch epiphyte assemblages in the forest interior and on the clearcut edge of a 700-year-old Douglas-fir canopy in western Oregon. Bryologist, 98: 301-312.

Sillett, S.C., and McCune, B. 1998. Survival and growth of cyanolichen transplants in Douglas-fir forest canopies. Bryologist, 101: 20-31.

Sillett, S.C., and Neitlich, P.N. 1996. Emerging themes in epiphyte research in westside forests, with special reference to the cyanolichens. Northwest Sci. 70(Spec. Issue): 54-60.

Sillett, S.C., McCune, B., Peck, J.E., Rambo, T.R., and Ruchty, A. 1999. Dispersal limitations of epiphytic lichens result in species dependent on old-growth forests. Ecol. Appl. In press.

Jandal Corp. 1994. SigmaPlot for Windows ${ }^{\mathrm{TM}}$, version 2.0 edition. Jandal Corp., San Rafael, Calif.

Sokal, R.R., and Rohlf, F.J. 1995. Biometry. 3rd ed. W.H. Freeman \& Co., New York.

Sollins, P., Grier, C.C., McCorison, F.M., Cromack, K., Fogel, R., and Fredriksen, R.L. 1980. The internal element cycles of an old-growth Douglas-fir ecosystem in western Oregon. Ecol. Monogr. 50: 261-285. 
SPSS, Inc. 1988. SPSS/PC+, version 3.0 edition. SPSS, Inc., Chicago, Ill.

Stiles, E.W. 1978. Avian communities in temperate and tropical alder forest. Condor, 80: 276-284.

Swanson, F.J., and Franklin, J.F. 1992. New forestry principles from ecosystem analysis of Pacific Northwest forests. Ecol. Appl. 2: 262-274.

U.S. Department of Agriculture (USDA). 1994. Final supplemental environmental impact statement on management of habitat for late-successional and old-growth forest related species within the range of the northern spotted owl. Appendix J2. Results of additional species analyses. U.S. Forest Service, Portland, Oreg. Van Pelt, R., and North, M.P. 1996. Analyzing canopy structure in Pacific Northwest old-growth forests with a stand-scale crown model. Northwest Sci. 70(Spec. Issue): 15-30. 